\title{
Out of the Box
}

\section{The value of industry}

In my last column I compared nutrition science congresses with food manufacturing industry trade fairs ${ }^{1}$. So some readers think I am 'against industry'. Not so. What could it mean to be against industry, in any sense? Take me. I can live in Brazil and work internationally because of relatively cheap and accessible communications. I enjoy supermarket food as well as that from my garden. To be against industry - in our context, the food industry - is meaningless, except perhaps in a dream of an Eden whose people feast on fruits of the earth, waters and air.

Besides, public health needs industry. The Danish and British wartime programmes that improved public health by means of good food were planned by governments and made to work by industry ${ }^{2,3}$. Successful peacetime programmes like those in Norway and Finland involve industry as indispensable partners ${ }^{4-6}$. It is right to identify industry as a lead player in global policy, together with UN agencies, national governments and non-government organisations (NGOs) ${ }^{7}$.

Justified hostility is directed not against industry in general, but those transnational food, drink and chemicals manufacturers - and their front organisations - whose products in quantities typically produced and consumed are reliably believed or agreed to be problematic or harmful, who use techniques of attack and defence like those of Big Tobacco, who pretend that they represent industry as a whole and thus gull UN agencies, governments and others that should know better, and who are undermining the new WHO global strategy on the prevention of chronic diseases by means of healthy food $^{8,9}$. Let's stop using the term 'food industry' and get specific and meaningful.

\section{The abuse of government}

Besides which, the problem is not primarily industry and pursuit of profit, but government and abuse of power. Let me explain, with a current example.

The UN Standing Committee on Nutrition (SCN), a coalition of UN agencies with member states and NGOs, is a unique forum for the development of global strategies. This year's meeting, the second chaired by Catherine Bertini - previously with the World Food Program and before then the US Departments of Health and of Agriculture during the Reagan and then elder Bush administrations, is being held in New York at the UN.

I learned some time before the meeting that members of the SCN steering group from UN agencies were in favour of looking for money from the food manufacturing industry to pay for travel and accommodation of potential SCN delegates notably from Asia and Africa, unable to find their own funding. My opinion was sought.

So here are five questions, answered from my experience. (1) Would a food manufacturer - Nestlé comes to mind, very powerful and very active in the South - give money unconditionally and not for instance discreetly suggest suitable delegates? Maybe. (2) Once such sponsorship was built into plans and budgets, might such suggestions be made in later years? Yes. (3) Given such funding, would SCN executives avoid people hostile to the funders - a hot issue with Nestlé ${ }^{10,11}$ ? The answer never to be admitted - is yes. (4) In corporate statements and negotiations with governments and regulators, would food manufacturers refer to their 'partnership' in ways that implied UN endorsement of their policies, practices and even products, despite UN policy to the contrary ${ }^{12}$ ? Of course, yes. (5) Is this a good use of the reputation of the $\mathrm{UN}$, its agencies and the SCN? Since my view is that expressed in current UN General Assembly guidelines on working with industry ${ }^{13}$, I say no.

After what I understand was a vigorous debate in which other members of the SCN steering group disagreed with those from UN agencies, food manufacturers will not be sponsors of the 2004 SCN meeting and, instead, the funds will be sought from the right sources - the UN agencies themselves. Watch this space.

\section{The attack on the UN}

But an ill wind blows on the UN agencies. In my review of last year's SCN meeting in Chennai, I noted the drive of the UN system to institute "public-private partnerships ${ }^{14}$. Initiatives like the Global Alliance for Improved Nutrition (GAIN), a creature of the Gates Foundation, are not incidents. They are manifestations of what the elder Bush termed 'the new world order', which is literally mindboggling, beyond our ability fully to comprehend. This is not surprising: the last attempt to dominate the world, by the British, began to collapse long before anybody now alive was born.

As I see it, the accelerating privatisation of the UN system, just like the process that created the Manhattan Project and Big Science in the USA in the 1940s and $1950 \mathrm{~s}^{15}$, is driven not by money but by ideology. The US government and its client states are using their power to beggar the UN, in order to force the institution of programmes in line with their policies of political and economic globalisation or - let's tell it like it is - the aggressive exercise by the current US government of its global hegemony. 
The UN agencies are being pushed to look for money from transnational industries - which like the East India companies at the time of European empires are the forerunners of imperialism - to soften them up ${ }^{16,17}$. Similarly, the US government is putting pressure on new WHO Director-General Lee Jong-wook, elected by the narrowest of majorities last May after lobbying on his behalf by the US government, to eviscerate the WHO global strategy on the prevention of chronic diseases by means of healthy food, primarily not for commercial but political reasons ${ }^{7-9}$. As this process continues, the powerful people within the UN system who are comfortable with 'the new world order' get promoted and become stronger. This is the context of 'publicprivate-people partnerships'. How easy it may be to bring Dr Lee to heel will be evident at this May's World Health Assembly.

\section{Chinatowns}

Now for another theme. Ricardo Uauy reminds me that during our dawn swims in Acapulco last November ${ }^{1}$, we discerned the imminent great debate in nutrition science between specialists and generalists, reductionists and integrators - those who favour or only accept evidence from increasingly precise studies whether of human populations or at a sub-cellular level, and those who see nutrition as embracing many inter-related disciplines, including history. The result of the debate should determine the future of nutrition science. As Presidentelect of the International Union of Nutritional Sciences (IUNS), a physician and a public health nutritionist, a citizen of Chile whose family came from Palestine, and a popular and genial character, Ricardo himself might reconcile all but the most obdurate warring factions.

Such debates transcend science; they are metaphysical, which is to say philosophical in nature ${ }^{18}$. Big picture advocates, of whom I am one ${ }^{19}$, are more comfortable with such a process; atomists are more inclined to see it as indulgent or irrelevant.

Here is a test of where you stand: news that the Chinese government plans the biggest migration in history, of 300500 million people, from rural areas into cities ${ }^{20}$.

Master-mind Wang Mengkui, head of the Beijing government's think-tank, is quoted as saying that the Chinese urban population, now at 39\%, 'is equivalent only to that of the UK in the 1850s, of the US in 1911, and of Japan in 1950'. He plans an urban population of 55-60\% by 2020. Motivations are economic and political: rural migrants are cheap labour for the factories that are making China the 'workshop of the world', and it suits politicians to concentrate voters in cities whose poor depend on government programmes for clean water, food, work and other entitlements.

My test is this. Do you read the story just as an interested or concerned citizen? Or do you see the revolutionary implications for public health nutrition in China, and indeed for everywhere in the world, as rural people are pushed into megapolises?

Those of us based in the South may be more likely to see wider horizons. Take Brazil, a country whose 'demographic transition' is now way ahead of China's. In 1950 about 20 million or $40 \%$ of Brazilians lived in towns and cities. The 2000 figure was about 140 million or $80 \%{ }^{21}$. Differences with China include Brazil's fragile national identity, multiplication of its population, and its political and financial domination by Washington. But Brazil predicts what would happen in China if Dr Wang's master-plan were realised. When I refer below to Rio de Janeiro and São Paulo, think also of Shanghai, Beijing and other cities in China, including many that are now small towns, and scale up the numbers seven times to allow for the difference in populations.

I am writing this on a top floor of one of the scores of high-rise apartment blocks in Barra da Tijuca, the middleclass suburb of Rio which a generation ago was not much more than a fishing village. These blocks are fortresses protected by railings, cameras, panic buttons and armed guards. A short drive down the freeway blasted through the mountain is Rocinha, whose 400000 inhabitants make it the biggest single favela (shanty city) in Rio. The interrelated trade in drugs and guns rises exponentially.

Another indicator of economic development of Brazil is annual expenditure of SUS24 billion (repeat, billion) on security systems, a healthy item in national GDP; together with all the other use of money needed to service murders (increased from 10000 in 1980 to 40000 in 2000), the kidnap boom in São Paulo and rocketing rates of general mayhem. The chief of the Rio military police says that the city is out of control ${ }^{22}$.

Reasons for the favelas that surround the cities of Brazil, and that have taken over inner-city slums and steep hills, include government policies that still push communities off the land. Urban people use more money, so Brazil has become more 'developed'. Most impoverished favela families are trapped, and those who have lost the land in which they had formal or informal rights can never go back. Without education or prospects, many become servants or drifters, some bandits or prostitutes. After poverty, the federal government has identified abuse of children, including their trade, whole for sex or cut up for their vital organs - which also goes to make Brazil more 'developed' - as its most urgent national priority. As a student of history Dr Wang may see some analogy with the London of Charles Dickens and the Manchester of Frederick Engels.

Rich people in Barra da Tijuca live well. As in the USA, supermercados are cornucopias of food, and magazines regularly feature advice on estilo da vida. There is less awareness of obesity than in the UK or USA: a chain of churrascaria (all-you-can-eat meats on the skewer) restaurants is called 'Porcão', meaning 'great big fat pig' 
and looking like porção or 'portion'. Magnified old habits are creating new problems. Nationally, consumption of vegetables and fruits is similar to that in Northern Europe. Consumption of saturated fat is rising, that of sugar remains high and of salt extremely high ${ }^{23}$. Bingeing on cachaça or pinga, the Brazilian sugar-cane spirit that costs less than imported water in the shops, contributes to an annual 40000 road deaths and rates of urban violence that explain why on New Year's Eve highways in and around Rio were often blocked by cars with flashing lights and nervous policemen with drawn guns ${ }^{24}$.

On New Year's Day I went to see 'O Senhor dos Aneis' at the New York shopping centre in Barra, whose landmark is a three-storey fibreglass Statue of Liberty. Like the inquisitive hobbit who sees the future of Middle-earth in a crystal ball, I see China in 2020 and 2050, within the lives of some readers of this column, as the one country able to balance the USA, politically, economically and ideologically. But will China then demonstrate its 5000 years of continuous history? Or will it be the eventual burgerised Asiatic conquest, its culture an oriental Disneyworld? The crystal ball is obscure.

What we can predict is that, between now and then, age-related rates of obesity, diabetes, heart disease and cancer will continue to soar in China. Public health nutritionists will chronicle this shift, and the teaching and profession of nutrition will expand in China. But will public health nutrition be part of the solution or part of the problem, in Brazil, China or anywhere else in the world? Think on these things.

\section{The colour of money}

Back to money and power. Claus Leitzmann, Treasurer of the IUNS, asks me where money for nutrition congresses should come from. Should the organisers of the 2005 and 2009 IUNS congresses in South Africa and Thailand accept money and other support from industry? And indeed, how should UN agencies, governments and NGOs relate to industry?

If I were organising a nutrition congress I would energetically seek funds and material support from industry, and its involvement in the professional and scientific process. First, it is practically impossible to mount a congress without industry support, unless most people attending are rich or paid with public money. Second, I believe congresses concerned with the application of science should involve industry, not merely for material support, but within the meetings themselves.

Third, the idea that industry money is 'black' and that money from other sources is 'white' is naïve. Funding bodies usually have agendas that they seek to impose. Even good people often require their bequests to charity to be spent in specified ways. If the issue is distortion or corruption of science, or the use of science as whitewash, industry is not the most problematic source of money.
Funding for a nutrition congress from say, the World Bank or the Gates Foundation, is at least as tricky as from, say, Walmart or Danone, and more so than that from say, an insurance or airline company.

But! I would seek industry support according to rules and guidelines discussed, agreed and published in a democratic and accountable way. The perception that practically all money is some shade of grey should discourage sanctimony. It also lays responsibility on those seeking support openly to discuss and disclose rules and guidelines.

Guidelines on relations with industry issued by the UN, UNICEF and WHO ${ }^{12,13,25}$ are written skilfully. Sometimes they are specific: UNICEF guidelines prohibit deals with manufacturers of landmines, cigarettes and alcohol. But usually they allow wide interpretation. Thus WHO guidelines say 'funds may not be sought or accepted from enterprises that have a direct commercial interest in the outcome of the project towards which they would be contributing'. Applied to UNICEF this might seem to rule out deals with McDonalds and Coca-Cola. But legal wordsmiths might say that Ronald McDonald House Charities ${ }^{\circledR}$ is not an enterprise but not-for-profit, and CocaCola has no direct interest in UNICEF programmes.

UN agencies, national governments and professional associations like IUNS have thought about how to relate to the cigarette, whisky and wild wild warmongery industries, but not food manufacturers and the food industry in general. The issue is more subtle, because we need food, and no food or drink is poison in the usual sense.

\section{The role of Public Health Nutrition}

Principles are needed, to govern rules and guidelines on relations with funders. They should be applied to UN agencies, governments, universities and research centres and all types of NGO; to core funding, research and all other programmes; and to relevant individuals and groups of people. The SCN should be an ideal forum for their initial drafting. Successive drafts should then be subject to a consensus process. Public Health Nutrition is an ideal journal for publication once agreed. Here are three principles that occur to me.

- Money and other material support from sources with a commercial or political interest in the outcome of the project, and thus a potential conflict of interest, are not acceptable. This rules out sectors of industry dependent on specific types or ranges of products, and not-forprofit bodies funded by such sectors.

- All material support to be specified with its source, amount and conditions, and this information fully disclosed both by the supplier and those in receipt of support, on websites, on research findings as submitted (with a summary for publication), and in conference programmes and proceedings. 
- All in receipt of material support to publish their rules and guidelines in full on their websites, to review them annually in the light of experience, advice and best practice, and to enable and encourage discussion among those they are established to serve. This should include regular debates at conferences and in journals.

Esté Vorster, chair of the organising committee of IUNS 2005, who is indeed energetically seeking funds for the congress $^{26}$, tells me that 'one of the aims of this congress is to put the spotlight on funding of nutrition events' (Vorster $\mathrm{H}$, personal communication). It is good to see that a session on the funding of nutrition science policy and practice is included in the programme for the congress, with the rueful title of 'Negotiating the impossible ${ }^{, 27}$, and also that the IUNS guidelines on funding require full disclosure of its sources and uses ${ }^{28}$.

Rules and guidelines can never cover all cases. It is best to agree clear and explicit rules, and then allow exceptions agreed by a body independent both of the potential giver and receiver of material support, as long as proposals are openly discussed and decisions published. Bodies with formal responsibility for overall governance, such as the UN General Assembly and NGO boards of trustees, may be counted as independent.

Much depends on whether the parties want to play by the spirit as well as the letter of the rules. One guiding light is: If disclosure of the source, nature or extent of money or other material support would when fully disclosed embarrass those giving or receiving support, it is best not to do a deal.

The future of nutrition science and its expression as food policy should be in proud collaboration with industry, accepting that science and industry have separate responsibilities. This means strong leadership within nutrition science, extraordinary consciousness, willingness and ability to work within global teams, as industry habitually does, and identification and consolidation of joint objectives. These could include the transformation of global food systems to favour plantbased food; the gradual phasing out of all methods of food processing known to be harmful to human health; and the reconciliation of biological, environmental and ecological objectives.

I propose that the first initiative come from IUNS. This implies that IUNS itself is determined to be transparent in its own dealings with industry.

\section{Geoffrey Cannon}

Geoffreycannon@aol.com

\section{References}

1 Cannon G. Making history, and other stories [Out of the Box]. Public Health Nutrition 2004; 7(1): 3-6.
2 Griggs B. The Food Factor. Why We Are What We Eat. London: Viking, 1986.

3 Drummond J, Wilbraham A. The Englishman's Food. Five Centuries of English Diet. London: Pimlico, 1991.

4 Milio N. Norwegian nutrition policy. In: Milio N, Helsing E, eds. European Food and Nutrition Policies in Action. World Health Organization (WHO) Regional Publications European Series No. 73. Copenhagen: WHO, 1998.

5 Puska P, Tuomilehto J, Nissinen A, Vartianen E, eds. The North Karelia Project. 20 year Results and Experiences. Helsinki: National Public Health Institute, 1995.

6 Puska P. Nutrition and mortality: the Finnish experience. Acta Cardiologica 2000; 55(4): 213-20.

7 World Health Organization (WHO). Integrated prevention of noncommunicable diseases. EB 113/44, 113/44 Add. 1, 27 November 2003 (available at www.who.int).

8 Commercial Alert. Secret document shows Bush administration effort to stop global anti-obesity initiatives. Media release, 14 January 2004 (available at www.commercialalert.org)

9 Boseley S. US accused of sabotaging obesity strategy. The Guardian, 16 January 2004.

10 Palmer G. The Politics of Breastfeeding. London: Pandora, 1988.

11 Baby Milk Action. Update 33, Summer 2003 (available at info@babymilkaction.org).

12 United Nations Children's Fund (UNICEF). Building Alliances for Children - Summary. New York: UNICEF, 2001.

13 United Nations (UN). Cooperation between the United Nations and All Relevant Partners, in Particular the Private Sector. Report of the Secretary-General. A/56/323. New York: UN, 28 August 2001.

14 Cannon G. The UN and the USA, and other stories [Out of the Box]. Public Health Nutrition 2002; 6(3): 229-31.

15 Fuller S. Thomas Kubn. A Philosophical History for our Times. Chicago, IL: University Press, 2000.

16 James L. The Rise and Fall of the British Empire. London: Little, Brown, 1994.

17 Hardt M, Negri A. Empire. Cambridge, MA: Harvard University Press, 2000.

18 Fuller S. Kuhn vs Popper. The Struggle for the Soul of Science. Cambridge: Icon, 2003.

19 Cannon G. The Fate of Nations. London: Caroline Walker Trust, 2003.

20 Dickie M, Kynge J. China may shift 500 million people in growth drive. Financial Times, 28 November 2003.

21 Instituto Brasileiro de Geografia e Estatistica. Results of the 2000 Census (available at www.ibge.gov.br).

22 Valente F. Securing nutrition in developed and developing countries. Paper for the ACC/SCN Fifth Report on the World Nutrition Situation, 2002. Available from fvalente@ technolink.com.br

23 Ministério da Saúde. Diretrizes Alimentares Officiais Brasileiras [Official Brazilian Dietary Guidelines]. Brasília: Ministério da Saúde, 2004, in preparation.

24 World Health Organization (WHO). Alcohol and Public Health in Eight Developing Countries. Geneva: WHO, 1999.

25 World Health Organization (WHO). Guidelines on interaction with commercial enterprises to achieve health outcomes. EB 107/20 Annex, 30 November 2000 (available at www.who.int).

26 IUNS. 18th International Congress. Nutrition Safari 2005 Sponsorship (available at www.puk.ac.za/iuns)

27 IUNS. 18th International Congress. Preliminary Programme (available at www.puk.ac.za/iuns).

28 IUNS. Guidelines for Funding of Activities (available from www.iuns.org) 